\title{
Clustering of 18 Local Black Rice Base on Total Anthocyanin
}

\author{
Kristamtini ${ }^{1}$, Endang Wisnu Wiranti ${ }^{2}$ \\ ${ }^{1,2}$ Assessment Institute for Agricultural Technology (AIAT) Yogyakarta \\ Jln. Stadion Maguwoharjo No. 22, Wedomartani, Ngemplak, Sleman, Yogyakarta, Indonesia \\ Author correspondency: \\ krisniur@yahoo.co.id ${ }^{1}$
}

\begin{abstract}
Black rice has a high anthocyanin content in the pericarp layer, which provides a dark purple color. Anthocyanin serve as an antioxidant that control cholesterol level in the blood, prevent anemia, potentially improve the body's resistance to disease, improve damage to liver cells (hepatitis and chirrosis), prevent impaired kidney function, prevent cancer/tumors, slows down antiaging, and prevent atherosclerosis and cardiovascular disease. Exploration results at AIAT Yogyakarta, Indonesia from 2011 to 2014 obtained 18 cultivar of local black rice Indonesia. The names of the rice are related to the color (black, red or purple) formed by anthocyanin deposits in the pericarp layer, seed coat or aleuron. The objective of the study was to classify several types of local black rice from explorations based on the total anthocyanin content. The study was conducted by clustering analyzing the total anthocyanin content of 18 local black rice cultivars in Indonesia. Cluster analysis of total anthocyanin content were done using SAS ver. 9.2. Clustering dendogram shows that there were 4 groups of black rice cultivars based on the total anthocyanin content. Group I consists of Melik black rice, Patalan black rice, Yunianto black rice, Muharjo black rice, Ngatijo black rice, short life of Tugiyo black rice, Andel hitam 1, Jlitheng, and Sragen black rice. Group II consists of Pari ireng, Magelang black hairy rice, Banjarnegara-Wonosobo black rice, and Banjarnegara black rice. Group III consists of NTT black rice, Magelang non hairy black rice, Sembada hitam, and longevity Tugiyo black rice. Group IV consist only one type of black rice namely Cempo ireng. The grouping result indicate the existence of duplicate names among the black rice namely Patalan with Yunianto black rice, and short life Tugiyo with Andel hitam 1 black rice.
\end{abstract}

Keywords: Clustering; black rice; exploration; total anthocyanin.

\section{INTRODUCTION}

Black rice is a type of rice, along with white rice and red rice. Black rice is not consumed as a staple food, but consumed as functional food by some communities. Functional food is a food which naturally or through a certain process contains one or more compounds considered to have physiological functions that are beneficial to health (Wijayanti, 2004). Black rice has a high anthocyanin content in the pericarp layer, which provides a dark purple color (Ryu et al., 1998; Takashi et al., 2001). Black rice is one of the functional foods because of its anthocyanin content. Anthocyanin pigments effectively reduce cholesterol levels in the human body (Lee et al., 2008). Anthocyanin has been recognized as functional health foodstuff due to its antioxidant activity (Satue-Gracia et al., 1997; Nam et al., 2006; Philpot et al., 2006).

Anthocyanin serve as an antioxidant that cleans blood cholesterol, prevent anemia, potentially increase body resistance to disease, improve liver cell damage (hepatitis and chirrosis), prevent impaired kidney function, prevents cancer/tumors, slows down antiaging (Harmanto, 2008), as well as to prevent narrowing of the arteries (atherosclerosis) and cardiovascular disease (Ling et al., 2001 and Ling et al., 2002).
Indonesia is a megabiodiversity country. Black rice is one of the wealth of Indonesia genetic resources that need to be conserved. Therefore, the explorations of black rice in the region of Yogyakarta and other regions in Indonesia are important. Eighteen black rice cultivars were collected by AIAT Yogyakarta, Indonesia. The name of the black rice was different, some even have no name, just given the name according to the farmers who cultivate it.

The difference in the name of black rice is allegedly caused by the diversity of the color of the rice, from bright black to black. The color difference of rice occurs as a result of differences in anthocyanin content. Characterization of morphological properties have been done, while the study of the diversity of anthocyanin content in some black rice has not been done. Solouki et al., (2008) suggests that the study of genetic diversity can be done with morphological, biochemical, and molecular markers. Biochemical studies of anthocyanin content in some black rice complement the morphological characterization, and was expected to help plant breeders to choose cultivars as parent in plant breeding programs.

Based on these considerations, this study aimed to classify the 18 black rice cultivars from Indonesia based on the total anthocyanin content. 


\section{MATERIALS AND METHODS}

The research began by planting 18 black rice cultivars from exploration (Table 1), and maintained until harvest. The black rice from the harvest were analyzed for the total anthocyanin content in the Agricultural Production Technology Laboratory of Gadjah Mada University Yogyakarta according to Lees \& Francis method (1972)
(Appendix 1). Clustering analysis of total anthocyanin were done using SAS ver software. 9.2. Cluster method was analyzed using hierarchical cluster analysis to know the kinship relationship. Hierarchical cluster analysis was a common way of grouping objects in groups that share resemblance to each other.

Table 1. Eighteen black rice cultivars were collected by AIAT Yogyakarta, Indonesia.

\begin{tabular}{lll}
\hline Black Rice Cultivar & Code & Origin \\
\hline 1. Melik & A & Bantul, Yogyakarta, Indonesia \\
2. Jlitheng & B & Sleman, Yogyakarta, Indonesia \\
3. Cempo ireng & $\mathrm{C}$ & Sleman, Yogyakarta, Indonesia \\
4. Pari ireng & $\mathrm{D}$ & Sleman, Yogyakarta, Indonesia \\
5. Beras hitam NTT & $\mathrm{E}$ & NTT, Indonesia \\
6. Beras hitam Bantul & $\mathrm{O}$ & Bantul, Yogyakarta, Indonesia \\
7. Beras hitam Magelang berbulu & $\mathrm{R}$ & Magelang, Jawa Tengah, Indonesia \\
8. Beras hitam Magelang tak berbulu & $\mathrm{S}$ & Magelang, Jawa Tengah, Indonesia \\
9. Beras hitam Sragen & $\mathrm{T}$ & Sragen, Jawa Tengah, Indonesia \\
10. Beras hitam banjarnegara berbatasan wonosobo & $\mathrm{W}$ & Banjarnegara, Jawa Tengah, Indonesia \\
11. Beras hitam banjarnegara & $\mathrm{Y}$ & Banjarnegara, Jawa Tengah, Indonesia \\
12. Beras hitam Tugiyo umur panjang & AA & Bantul, Yogyakarta, Indonesia \\
13. Sembada hitam & AB & Sleman, Yogyakarta, Indonesia \\
14. Beras hitam Muharjo & AC & Bantul, Yogyakarta, Indonesia \\
15. Beras hitam Patalan & AD & Bantul, Yogyakarta, Indonesia \\
16. beras hitam Tugiyo umur pendek & AE & Bantul, Yogyakarta, Indonesia \\
17. Andel hitam 1 & AF & Kulon Progo, Yogyakarta, Indonesia \\
18. Beras hitam Yunianto & AG & Bantul, Yogyakarta, Indonesia \\
\hline
\end{tabular}

\section{RESULTS AND DISCUSSION}

Black rice was one of functional foods due to anthocyanin content that expressed in rice color. Black rice is one of anthocyanin sources. Other anthocyanin source are fruits, vegetables, and grains that have given color pigments. Healthy foods usually have a black or purple color, but in terms of appearance, this color less appealing. Most plants have the largest anthocyanin content in fruit (Houghton \& Hendry 1995). Some plants, such as tea, cocoa, cereals, beans, red cabbage, and petunias have anthocyanins in plant parts other than fruits (Lila 2004; Sterling 2011). Anthocyanins also found in foods that have red, purple to black pigments such as black soybeans, black sesame, blackberry, and grapes.

Foods consumed daily are often sources of free radicals that harmful to the body. Free radicals can accelerate the aging process and increase the risk of diseases such as heart disease, stroke, diabetes, arthritis, and cancer. Body damage due to free radical attack can be prevented by antioxidants. Free radicals are atoms or molecules that are very active and unstable because the structure of an atom or its molecule has an unpaired electron. In order to be stable, these atoms or molecules need to get another electron by taking an electron from another molecule. Anthocyanin can serve as an antioxidant, a compound capable of donating its electrons to neutralize the damaging properties of free radicals (Bustanul 2007).

Based on these matters then conducted analysis of total anthocyanin content on 18 local black rice collection of AIAT of Yogyakarta. The total anthocyanin content of 18 black rice cultivars is presented in Table 2.

Table 2 shows that each black rice cultivar contains anthocyanin content varying from 53.22 to $428.38 \mathrm{mg} /$ $100 \mathrm{~g}$, according to its genetic potential. The total anthocyanin content is expressed as the color of rice, and the color of rice from each rice cultivar is presented in Figure 1. 
Table 2. Total anthocyanin content in 18 black rice cultivars.

\begin{tabular}{lcc}
\hline Black Rice Cultivar & Code & Total Anthocyanin $\mathbf{( m g / 1 0 0 ~ g )}$ \\
\hline 1. Melik & $\mathrm{A}$ & 100.06 \\
2. Jlitheng & $\mathrm{B}$ & 53.22 \\
3. Cempo ireng & $\mathrm{C}$ & 428.38 \\
4. Pari ireng & $\mathrm{D}$ & 230.48 \\
5. Beras hitam NTT & $\mathrm{E}$ & 264.43 \\
6. Beras hitam Bantul & $\mathrm{O}$ & 90.22 \\
7. Beras hitam Magelang berbulu & $\mathrm{R}$ & 196.34 \\
8. Beras hitam Magelang tak berbulu & $\mathrm{S}$ & 288.53 \\
9. Beras hitam Sragen & $\mathrm{T}$ & 65.04 \\
10. Beras hitam banjarnegara berbatasan wonosobo & $\mathrm{W}$ & 179.09 \\
11. Beras hitam banjarnegara & $\mathrm{Y}$ & 165.78 \\
12. Beras hitam Tugiyo umur panjang & $\mathrm{AA}$ & 298.93 \\
13. Sembada hitam & $\mathrm{AB}$ & 284.05 \\
14. Beras hitam Muharjo & $\mathrm{AC}$ & 122.45 \\
15. Beras hitam Patalan & $\mathrm{AD}$ & 107.22 \\
16. Beras hitam Tugiyo umur pendek & $\mathrm{AE}$ & 81.81 \\
17. Andel hitam 1 & $\mathrm{AF}$ & 82.55 \\
18. Beras hitam Yunianto & $\mathrm{AG}$ & 107.39 \\
\hline
\end{tabular}

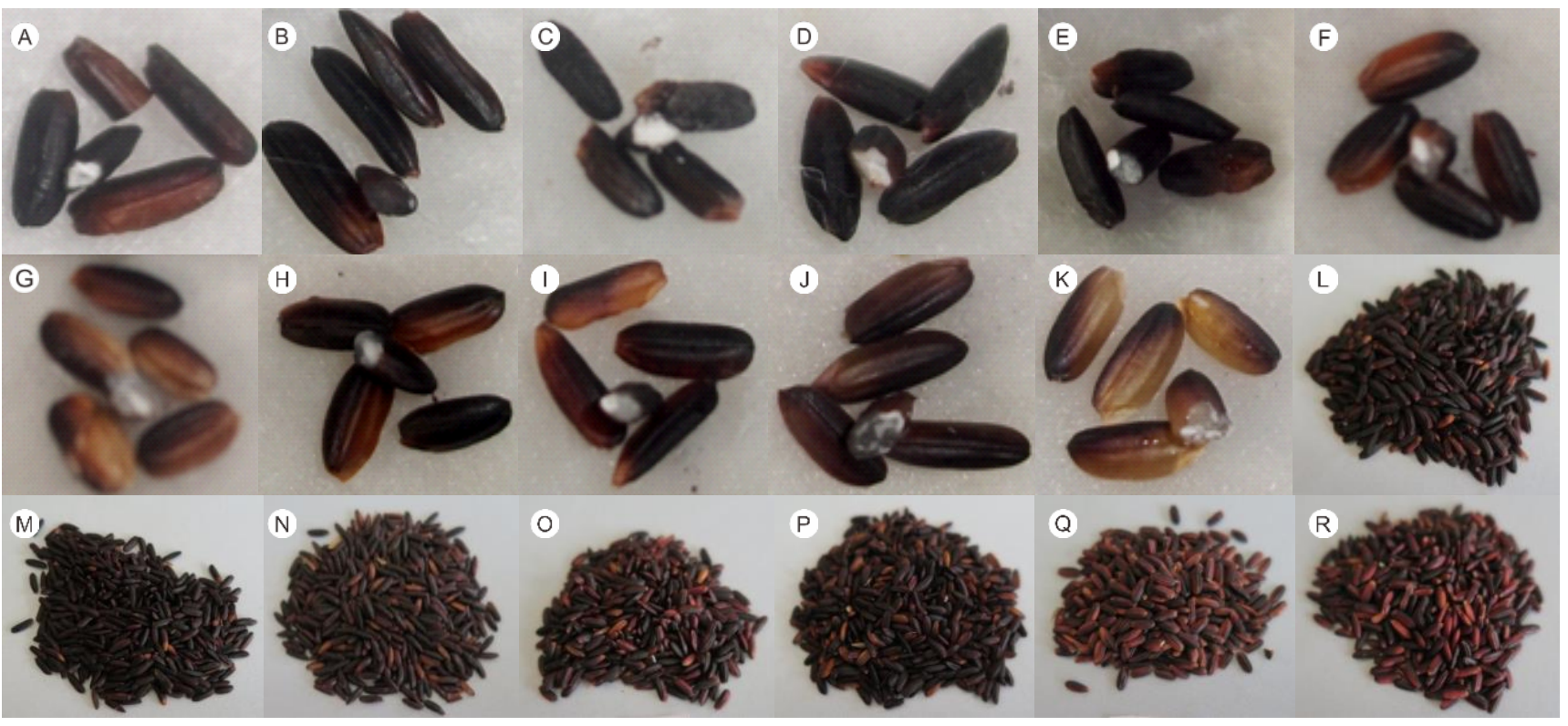

Figure 1. Appearance of rice color from 18 black rice cultivars. (A). Melik; (B). Jlitheng; (C). Cempo ireng; (D). Pari ireng; (E). Beras hitam NTT; (F). Beras hitam Bantul; (G). Beras hitam Magelang berbulu; (H). Beras hitam Magelang tak berbulu; (I). Beras hitam Sragen; (J). Beras hitam banjarnegara berbatasan wonosobo; (K). Beras hitam banjarnegara; (L). Beras hitam Tugiyo umur panjang; (M). Sembada hitam; (N). Beras hitam Muharjo; (O). Beras hitam Patalan; (P). Beras hitam Tugiyo umur pendek; (Q). Andel hitam 1; (R). Beras hitam Yunianto.

Black rice has a high anthocyanin content in the pericarp layer, which provides a dark purple color. The color difference of rice is regulated genetically. According to Chang \& Bardenas (1965), the color of rice is determined by the pigments in the pericarp and the tegmen, namely white, bright red, red, reddish brown, brown, grayish, gold, purple, and purple (almost black), while endosperm from all rice varieties was white. Ayoola \& Faluyi (2007), said that pericarp rice seeds are usually white but may be red, brown or almost purple, pigmentations/colorations are no deeper than pericarp and endosperm was always white.

Clustering of black rice based on total anthocyanin content in 18 black rice cultivars in the form of dendogram in Figure 2. 

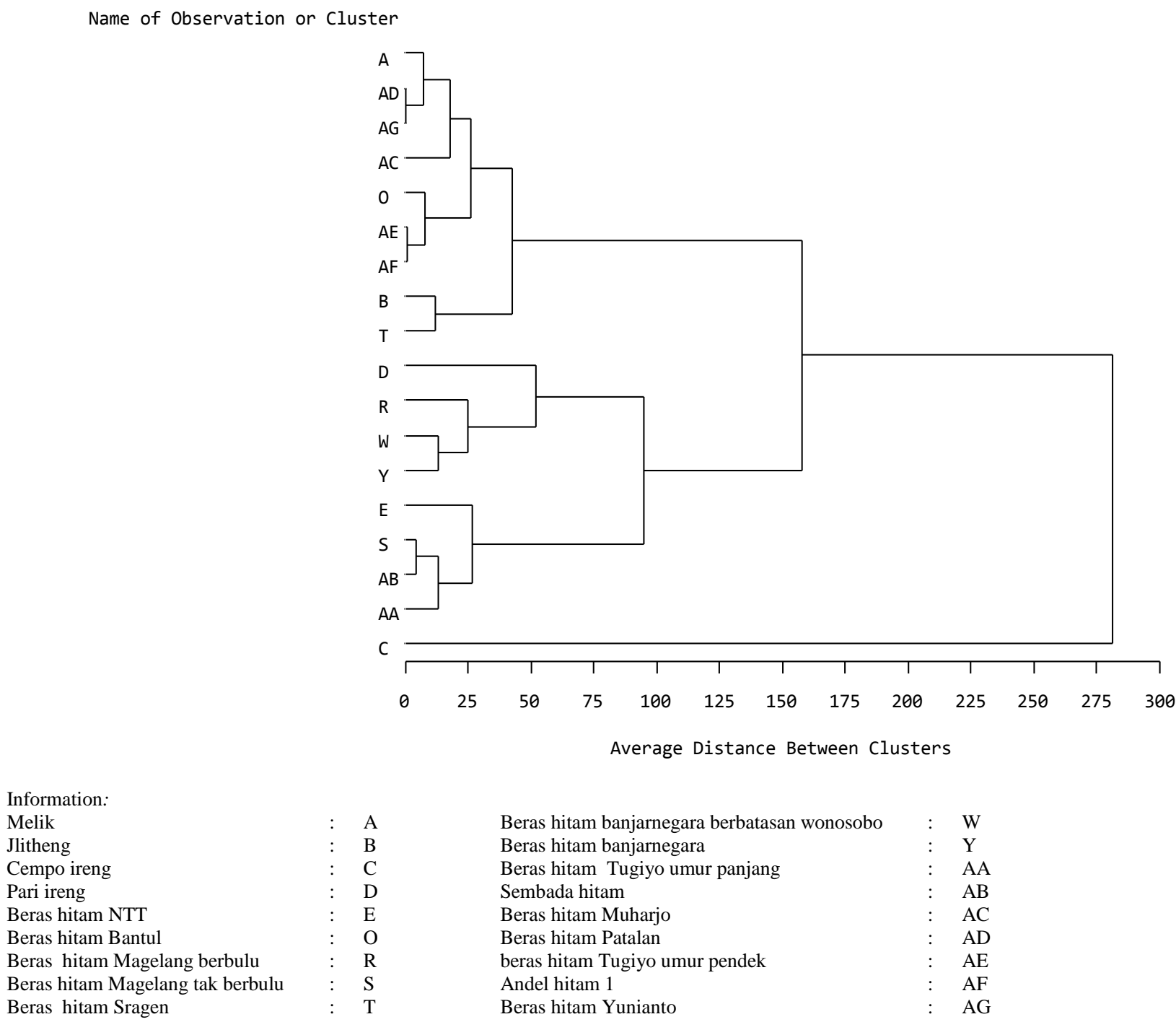

Beras hitam banjarnegara berbatasan wonosobo
Beras hitam banjarnegara
Beras hitam Tugiyo umur panjang
Sembada hitam
Beras hitam Muharjo
Beras hitam Patalan
beras hitam Tugiyo umur pendek
Andel hitam 1
Beras hitam Yunianto

Figure 2. Dendogram of clustering of 18 black rice cultivars based on the total anthocyanin content.

Dendogram in Figure 2 shows that 18 black rice cultivars based on their total anthocyanin content were divided into 3 groups. Group I consists of A (Melik), AD (Beras hitam Patalan), AG (Beras hitam Yunianto), AC (Beras hitam Muharjo), O (Beras hitam Bantul), AE (beras hitam Tugiyo umur pendek), AF (Andel hitam 1), $\mathrm{B}$ (Jlitheng), and $\mathrm{T}$ (Beras hitam Sragen). Group II consists of D (Pari ireng), R (Beras hitam Magelang berbulu), W (Beras hitam banjarnegara berbatasan wonosobo), Y (Beras hitam banjarnegara), E (Beras hitam NTT), S (Beras hitam Magelang tak berbulu AB (Sembada hitam) and AA (Beras hitam Tugiyo umur panjang). Group III consists of only cultivar $\mathrm{C}=\mathrm{Cempo}$ ireng, because Cempo ireng has the highest anthocyanin content of $428.38 \mathrm{mg} / 100 \mathrm{~g}$. It appears in Figure 2 that, in Group 1, there are 2 cultivars that have the same genetic distance as the total antioxidant content, that was $\mathrm{AD}$ (Beras hitam Patalan) and AG (Beras hitam Yunianto). Two other cultivars in group I also have the same genetic distance, thas was AE (beras hitam Tugiyo umur pendek) and AF (Andel hitam 1). The cultivars are allegedly the same or there was duplication of names based on their total anthocyanin content. The result of clustering based on the total anthocyanin content still needs to be supported by clustering based on plant morphology, such as plant height, plant age, stem color, leaf color, leaf tongue color, leaf ear color and so forth.

\section{CONCLUSION}

The total anthocyanin content in 18 black rice cultivars of AIAT of Yogyakarta collection varies according to its genetic potential. There are 3 groups of black rice based on the total anthocyanin content, some cultivars have the same genetic distance (close kinship relationship) and there were suspected duplication of the name based on the total anthocyanin content. 


\section{SUGGESTION}

Required clustering of black rice cultivars based on morphological properties to support of clustering based on the total anthocyanin content.

\section{REFERENCES}

Ayoola, A.O. and J.O. Faluyi. 2007. Inheritance of caryopsis/ ripened-hull colour in a selection from land races of rice Oryza sativa (Linn.). Agric. J. 2 (3): 412-414.

Bustanul. 2007. Manfaat beras hitam. http://bumiganesa.com. Harian Metro Online Friday, 08 June 2007. Retrieved at 28 April 2011.

Chang, Te-Tzu and E.A. Bardenas. 1965. The morphology and varietas characteristics of the rice plant. Technical Bulletin 4 December, 1965. IRRI.Los Baños, Laguna, The Philippines. $27-31$.

Harmanto, A. 2008. Varietas beras organik berdasarkan warna. http://aghribisnis-ganesha.com. p. 146 . Retrieved at 26 September 2008.

Houghton, J.D. and G.A.F. Hendry. 1995. Natural Food Colorants. Springer. pp. 53-59.

Lee, J.C., J.D. Kim, F.H. Hsieh, and J.B. Eun. 2008. Production of black rice cake using ground black rice and medium-grain brown rice. Int'l. J. Food Sci. Technol. 43 (6): 1078-1082

Lila, M.A. 2004. Anthocyanins and human health: An in vitro investigative approach. J. Biomed. Biotechnol. 5: 306-313. doi: 10.1155/S111072430440401X. http://www.ncbi.nlm. nih.gov/pmc/articles/PMC1082894/.

Ling, W. H., Cheng, Q. X., Ma, J. and Wang, T. 2001. Red and black rice decrease artherosclerotic plaque formation and increase antioxidant status in rabbits. J. Nutr. 131: 1421 - 1426.
Ling, W.H., L.L. Wang and J. Ma. 2002. Supplementation of black rice outer layer fraction to rabbits decreases the atherosclerotic plaque formation and increases antioxidant status. J. Nutr. 132: $20-26$.

Nam, S.H., S.P. Choi, M.Y. Kang, H.J. Koh, N. Kozukue, and M. Friedman. 2006. Antioxidative activities of bran from twenty one pigmented rice cultivars. Food Chem. 94: 613-620.

Philpot, M., K.S. Gould, C. Lim, and L.R. Ferguson. 2006. In situ and in vitro antioxidant activity of sweet potato anthocyanins. J. Agric. Food Chem. 54: 1710-1715.

Ryu, S.N., S.Z. Park, and C.T. Ho. 1998. High performances liquid chromatographic determination of anthocyanin pigments in some varieties of black rice. J. Food Drug Analysis 6: 1710-1715.

Satue-Gracia, M., I.M. Heinonen, and E.N. Frankel. 1997. Anthocyanins as antioxidants on human low-density lipoprotein and lechthin-liposome system. J. Agric. Food Chem. 45: 3362-3367.

Solouki, M., H., Mehdikhani, H. Zeinali \& A.A. Emamjomeh, 2008. Study of Genetik Diversity in Chamomile (Matricaria chamomilla) based on morphological traits and molecular markers. Sci. Hortic.

Sterling, R.D.M. 2011. Anthocyanins. The Chiropractic Resource Organization, 19 March 2011.

Takashi, I., X. Bing, Y. Yoichi, N. Masaharu and K. Tetsuya. 2001. Antioxidant activity of anthocyanin extract from purple black rice. J. Med. Food. 4: 211- 218.

Wijayanti, E. 2004. Potensi dan prospek pangan fungsional indigenous Indonesia. Presented at Seminar Nasional Pangan Fungsional Indigenous Indonesia: Potensi, regulasi, keamanan, efikasi dan peluang pasar. Bandung, 6-7 October 2004. 
THIS PAGE INTENTIONALLY LEFT BLANK 